\title{
A physiologically based model to capture species-dependent differences in oxygen distribution in the posterior eye
}

Carrie German ${ }^{1}$, Alex Boyer $^{1}$, Andrzej Przekwas ${ }^{1}$, Suzy El Bader ${ }^{2}$, Antonio Cabal ${ }^{2}$

${ }^{1}$ CFD Research Corp., Huntsville, AL, USA; ${ }^{2}$ Merck Sharp \& Dohme, Whitehouse Station, Rahway, NJ, USA

\section{Abstract}

Ocular barriers to drug transport make delivery of effective doses to posterior targets exceptionally difficult. Animal models have commonly been used to evaluate drug distribution and penetrability, but translational tools to determine human dosing are lacking. Here we present a framework for modeling interspecies variation by simulating oxygen distribution in the posterior eye, from outer vitreous to the sclera. Posterior eye models of mouse, rabbit, and human are presented with modifications based solely on species-dependent anatomical and physiological differences. The model includes tissue and vascular contributions to transport. In addition to oxygen, nitric oxide and its impact on oxygen metabolism is simulated. Depth-dependent retinal oxygen partial pressure profiles are in good agreement with experimental data for all three species. The model can be further extended to evaluate the variations of retinal oxygenation in response to various drugs, formulations, administration protocols, and treatment plans. Further, this framework of ocular physiologically based pharmacokinetic/pharmacodynamic models could support animal to human translation, a critical step in the drug development process.

Keywords: computational modeling, physiologically based, posterior eye, oxygen, translational tool

Correspondence: Carrie German, CFD Research Corporation, 701 McMillian Way NW, Suite D, Huntsville, AL, USA.

E-mail: carrie.german@cfdrc.com 


\section{Introduction}

Diseases impacting the posterior eye, such as glaucoma, diabetic neuropathy, and macular degeneration, continue to cause visual impairment and blindness. Despite numerous varied attempts to treat and cure these diseases, the problem remains and continues to grow. ${ }^{1,2}$ Of particular significance to treatment challenges are the many localized barriers to ocular transport, including tear turnover and drainage, corneal barriers, the blood-aqueous barrier, conjunctival and lymph flow, and retinal barriers.

These barriers make topical administration of traditional ophthalmic products challenging due to low bioavailability at posterior targets, allowing less than $5 \%$ of the active pharmaceutical ingredient (API) in eyedrops to reach ocular targets. ${ }^{3-5}$ On the other hand, systemic administration to achieve effective concentrations at posterior eye targets may require high drug doses that may result in adverse or even toxic effects. While intravitreal, scleral, and periocular injections/implants can improve the likelihood of achieving effective local API concentrations, such methods are extremely invasive and associated with increased risk. Much of the current research focuses on the design of specialized vehicles for enhanced residence time and ocular transport..$^{6-8}$

Specialized vehicle design requires a deep understanding of the barriers that stand between the site of API administration and the ocular target. In vitro cell cultures, ocular explants and animal models are typically used to better understand drug transport across these barriers and test treatments. Ophthalmic animal models present a number of different visually specialized ocular systems that can be used to address different questions. A significant amount of ophthalmic research is conducted on mice due to their relative proximity to human eyes and their unique genetic modification availability. ${ }^{9,10}$ of course, primate eyes also possess relative proximity to humans ${ }^{11}$ but are costly and pose ethical issues..$^{12,13}$ The rabbit is another animal model that is commonly used in ophthalmic research, ${ }^{14-17} \mathrm{f}$ with anatomical references dating back to the $17^{\text {th }}$ century. ${ }^{14}$ The rabbit eye model is ideal for ophthalmic research for several reasons: i) it is similar to humans, ii) the animal is relatively docile in nature, iii) they come in various sizes (breed-dependent), and iv) they are more economical compared to other mammals (i.e., primates)..$^{18}$

Animal testing is both time and cost intensive. Moreover, interspecies differences in anatomy and physiology contribute to vastly different pharmacokinetics (PK) and pharmacodynamic (PD) responses. A few examples of these differences include: i) presence versus absence of certain structures (i.e., the nictitating membrane), ii) tissue dimensions (i.e., surface area and thickness), and iii) vascularization location (i.e., vascular versus avascular retina). These differences can explain why so many new investigational drugs do not pass phase III clinical trials. ${ }^{19-21}$ The use of computational models in combination with animal testing could significantly decrease time and cost by filling in knowledge gaps and providing guidance for the 
development of therapeutic formulations and treatment protocols. Computational models should be capable of capturing species-dependent differences in PK and PD by accounting for ocular anatomical and physiological differences and should enable animal-to-human translation. As a first step toward this type of model development, we present physiologically based models of oxygen distribution and metabolism in the posterior eye for mouse, rabbit, and human. When combined with a physiologically based pharmacokinetic (PBPK) model it can be used as a PD model for predicting drug-induced retinal oxygenation responses

The retina is one of the highest oxygen and glucose consuming tissues, ${ }^{22}$ even exceeding consumption rates in the brain; ${ }^{23-25}$ thus, retinal oxygenation plays an important role in sustaining ocular health and function. Vascular systems supply ocular tissues with oxygen, glucose, and other nutrients and remove toxins/waste. Inadequate oxygenation of the eye can lead to adverse effects, including blurred vision and even blindness under chronic conditions. ${ }^{26}$ Hypoxic ocular states resulting in elevation of intraocular pressure have also been reported as one of the risk factors for glaucoma. ${ }^{27,28}$ Due to its importance to ocular health, retinal oxygenation has been studied extensively in a number of different animal models. With the availability of interspecies data sets and the essential role played in retinal function, oxygen distribution profiles provide an excellent model validation dataset.

\section{Methods}

\subsection{Model geometry}

The posterior eye is comprised of relatively thin tissue layers, which includes the retina, choroid, and sclera. The layout of the posterior eye model geometry is representative of this anatomy. The retina, located between the choroid and vitreous body/humor (Fig. 1), is comprised of the following layers (starting with the innermost
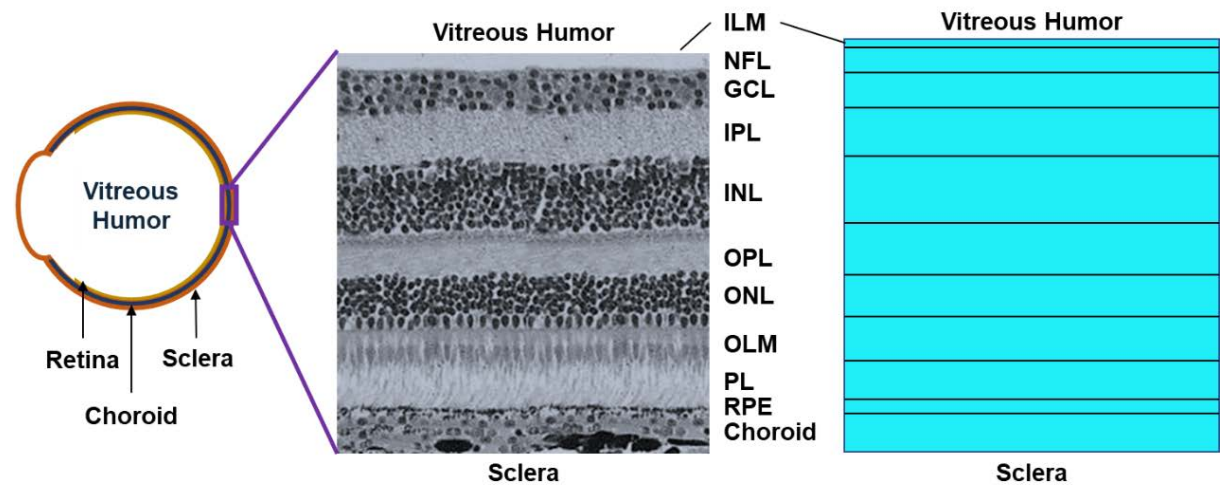

Fig. 1. Anatomical layers of the retina: in vivo and in silico compartmental model. 
Table 1. Anatomical parameters for the retinal physiology mode

\begin{tabular}{|c|c|c|c|}
\hline & Mouse & Rabbit & Human \\
\hline Layer & \multicolumn{3}{|c|}{ Thickness $(\mu \mathrm{m})$} \\
\hline Nerve fiber layer & $19.1^{29}$ & \multirow{3}{*}{$33.4^{30}$} & $23.6^{31}$ \\
\hline Ganglion cell layer & \multirow{2}{*}{$59.6^{29}$} & & $75.0^{31}$ \\
\hline Inner plexiform layer & & & $40.2^{31}$ \\
\hline Inner nuclear layer & $27.8^{29}$ & $17.5^{30}$ & $37.7^{31}$ \\
\hline Outer plexiform layer & $19.2^{29}$ & $8.50^{32}$ & $30.3^{31}$ \\
\hline Outer nuclear layer & $62.8^{29}$ & $19.1^{30}$ & $62.0^{31}$ \\
\hline Photoreceptors & $26.0^{29}$ & $28.5^{32}$ & $75.9^{33,34}$ \\
\hline Retinal pigmented epithelium & $18.2^{29}$ & $5.00^{32}$ & $26.3^{35}$ \\
\hline Choroid & $17.0^{36}$ & $80.0^{37}$ & $300^{36}$ \\
\hline Sclera & $15.0^{36}$ & $225^{38}$ & $600^{36}$ \\
\hline Surface & \multicolumn{3}{|c|}{ Area $\left(\mathbf{m m}^{2}\right)$} \\
\hline Retinal surface area & $15.6^{39}$ & $520^{40}$ & $1094^{41}$ \\
\hline
\end{tabular}

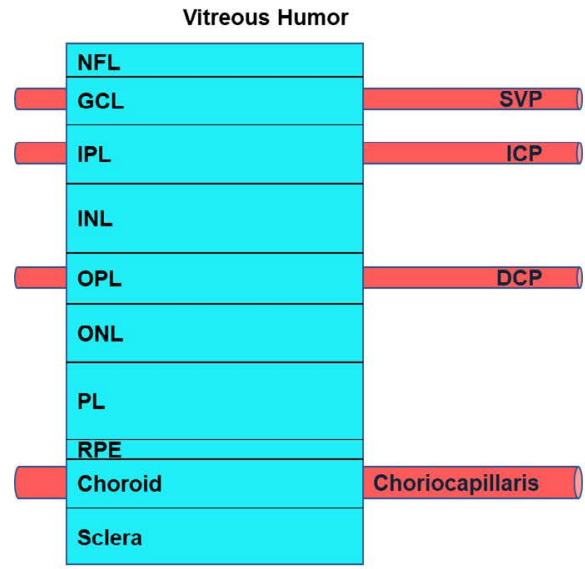

A) Human/Mouse

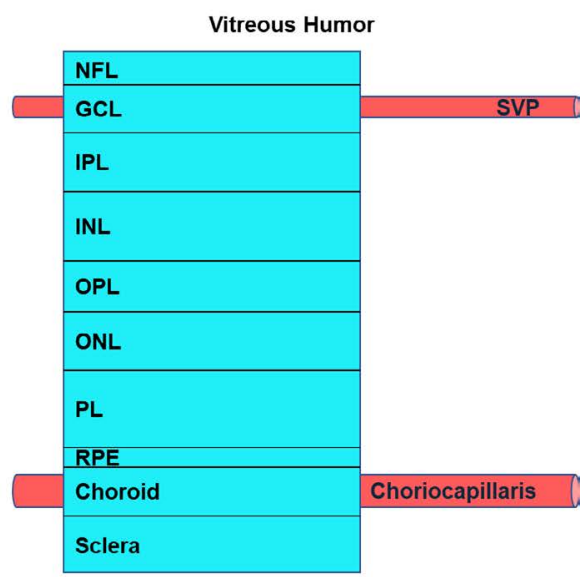

B) Rabbit

Fig. 2. Schematic of the posterior eye models for (A) mice and humans and (B) rabbits demonstrating differences in vasculature. 
near the vitreous humor): inner limiting membrane (ILM), nerve fiber layer (NFL), ganglion cell layer (GCL), inner plexiform layer (IPL), inner nuclear layer (INL), outer plexiform layer (OPL), outer nuclear layer (ONL), outer limiting membrane (OLM), photoreceptors (PL), and retinal pigmented epithelium (RPE). Figure 1 shows how the in silico model layers/compartments represent the in vivo posterior structure.

All dimensions of the compartmental layers are physiologically based and species-dependent. The common exchange area between the compartments is representative of the surface area of the retina. Layer thicknesses and other geometric parameters are listed in Table 1 by species.

Retinal vascularization plays important roles in oxygen and nutrient supply, toxin removal, and drug delivery. ${ }^{29}$ The outer retina is supplied by choroidal capillaries that originate from ciliary arteries, which originate from the ophthalmic artery, while the inner retina is perfused by the central retinal artery, also a branch of the ophthalmic artery. A well-organized ocular vascular system adapts to meet the metabolic requirements of the retina to ensure visual function. The choroid and specific layers of the retina are vascularized. ${ }^{29}$ On the other hand, blood supply in the sclera is minimal, warranting the assumption that the sclera is avascular. ${ }^{30}$

Tissue compartment volumes were calculated based on the retinal surface area and compartmental thickness. Ocular vascularization is species-dependent. In humans and mice, the retinal vessels exist within the GCL, IPL, and OPL. ${ }^{48}$ The superior vascular plexus (SVP) infiltrates the GCL, the intermediate capillary plexus (ICP) traverses the IPL, and the deep capillary plexus (DCP) is embedded in the OPL. In addition to the retinal vessels, choroidal vessels - the choriocapillaris (CIA) provide a much more significant blood supply. Compared to human, the rabbit has a significantly less vascularized retina that only contains the SVP. ${ }^{34,49}$ The species-dependent differences in the vasculature layout for the posterior eye models are shown in Figure 2.

Because retinal vasculature plays such a vital role in ocular transport, species-specific vasculature models such as these can help in identifying translational issues associated with differing PK and PD responses observed between animal models and humans. The vascular system acts both as a source and a sink to the connected tissues. Flow rate parameters were based on physiological values found in literature Table 2. Vascular surface area calculation estimates are given in Table 3.

Vessel density for the rabbit was not available in literature and so the surface area for the CIA and SVP were estimated at $550 \mathrm{~mm}^{2}$ and $15 \mathrm{~mm}^{2}$, respectively. Note that both values fall between the respective values for human and mouse. The average diameter of the vessels in each vascular system are provided in Table 4.

Vascular system volume $\left(V_{j}\right)$ was calculated as the volume of a cylinder, $V_{j}=0.5 \cdot A_{j} \cdot r_{j}$, where $A_{j}$ is the surface area and $r_{j}$ is the average radius of the vascular compartments represented by subscript $j(j=1,2,3,4$ for human and mouse and $j=$ 1, 2 for rabbit, Fig. 2). 
Table 2. Species-dependent posterior eye vasculature parameters

\begin{tabular}{|l|l|l|l|}
\hline Vasculature & Mouse & Rabbit & Human \\
\hline Choroidal blood flow $(\mathrm{mL} / \mathrm{h})$ & $1.52^{50 \dagger}$ & $53^{51}$ & $43^{52}$ \\
\hline Retinal blood flow $(\mathrm{mL} / \mathrm{h}):$ & $0.24^{50 \dagger}$ & $0.63^{51}$ & $4.8^{53}$ \\
\hline SVP & $0.11^{\star}$ & 0.63 & $2.2^{\star}$ \\
\hline ICP & $0.05^{\star}$ & -- & $1.5^{\star}$ \\
\hline DCP & $0.07^{\star}$ & -- & $1.1^{\star}$ \\
\hline
\end{tabular}

SVP: superior vascular plexus; ICP: intermediate capillary plexus; DCP: deep capillary plexus ${ }^{*}$ Calculated from capillary density determined by optical coherence tomography angiography. ${ }^{54}$

$$
\begin{aligned}
& Q_{O A}=Q_{C R A}+Q_{C I A} \\
& Q_{C R A}=Q_{C V P}+Q_{I C P}+Q_{D C P} \\
& Q_{S V P}=a_{C R A}+Q_{C R A} \\
& Q_{D C P}=a_{D C P} \cdot Q_{C R A} \\
& Q_{I C P}=a_{C P} \cdot Q_{C R A} \\
& a_{S V P}+a_{D C P}+a_{I C P}=1
\end{aligned}
$$

where $Q$ is the volumetric flow rate, $\alpha$ is the fractional capillary density. The subscripts indicate the following vasculature, OA: ophthalmic artery; CRA: central retinal artery; CiA: choriocapillaris/choroid.

†Calculated using a mouse retinal wet weight of $3.3 \mathrm{mg} .{ }^{55}$

Table 3. Vascular surface area calculated estimates

\begin{tabular}{|l|l|l|l|l|}
\hline \multirow{2}{*}{ Vascular system } & \multicolumn{2}{|l|}{ Vessel density range (\%) } & \multicolumn{2}{l|}{$\begin{array}{l}\text { Model value - } \\
\text { Surface area }\left(\mathbf{m m}^{2}\right) \dagger\end{array}$} \\
\cline { 2 - 5 } & Human & Mouse & Human & Mouse \\
\hline Choriocapillaris & $60.88 \pm 0.6556$ & $80 \% 57$ & 732 & 12.8 \\
\hline Superior vascular plexus & $32.97 \pm 3.9058$ & $31.3 \pm 2.559$ & 397 & 5.0 \\
\hline $\begin{array}{l}\text { Intermediate capillary } \\
\text { plexus }\end{array}$ & $45.05 \pm 5.3458$ & $13.4 \pm 2.159$ & 542 & 2.1 \\
\hline Deep capillary plexus & $37.34 \pm 4.9658$ & $20.3 \pm 2.659$ & 450 & 3.3 \\
\hline
\end{tabular}

${ }^{\dagger}$ Retinal exchange area $x$ vessel density. 
Table 4. Vascular system average diameter

\begin{tabular}{|l|l|l|l|}
\hline \multirow{2}{*}{ Vascular System } & \multicolumn{3}{l|}{ Model value $(\boldsymbol{\mu m})$} \\
\cline { 2 - 4 } & Mouse & Rabbit & Human \\
\hline Choriocapillaris & 25.060 & 20.061 & $25.062-64$ \\
\hline Superior vascular plexus & 11.065 & 8.4561 & 9.6566 \\
\hline Intermediate capillary plexus & 5.565 & -- & 8.0266 \\
\hline Deep capillary plexus & 5.565 & -- & 8.1266 \\
\hline
\end{tabular}

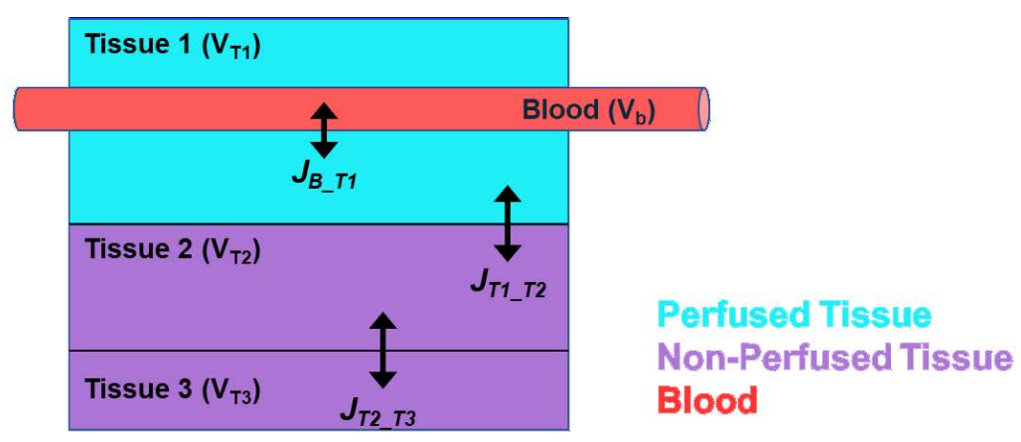

Fig. 3. Schematic representation of transport mechanisms in perfused and diffused tissue.

\subsection{Governing equations and boundary conditions}

\subsubsection{Modeling oxygen transport in the posterior eye}

Oxygen $\left(\mathrm{O}_{2}\right)$ transport in the posterior eye involves both diffusive and convective processes. Tissue-tissue and blood-tissue transport in the posterior eye segment are primarily dictated by diffusion, whereas the transport in the blood is dominated by the convective mechanism. Figure 3 shows these general transport considerations, where diffusive fluxes, $J$, are represented by the double-headed arrows and the convective transport, $Q$, is represented by the single-headed arrow.

\subsubsection{Blood oxygen transport}

Oxygen in the blood is exists in three forms: i) dissolved free oxygen in plasma, ii) dissolved oxygen in the intracellular fluid of red blood cells (RBCs), and iii) reversibly bound to hemoglobin $(\mathrm{Hb})$ inside of RBCs. Each of these contributes to the total partial pressure of oxygen in blood. Blood oxygen transport equations must consider all three blood component contributions. The dissolved $\mathrm{O}_{2}$ concentration is related to the partial pressure via Henry's Law: 


$$
\mathrm{C}_{\mathrm{O}_{2}}=\mathrm{a} P_{\mathrm{O}_{2}}
$$

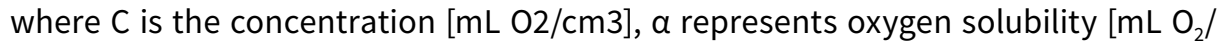
$\left.\mathrm{mmHg} / \mathrm{m}^{3}\right]$, and $\mathrm{P}$ is the partial pressure $[\mathrm{mmHg}]$.

Formulation of the conservation equation for blood oxygen in terms of partial pressure was derived from the model presented by Goldman and Popel, ${ }^{67-70}$ where the total concentration of free and $\mathrm{Hb}$ bound $\mathrm{O}_{2}$ is given by:

$$
P_{\mathrm{O}_{2}}=P_{b}=a_{P l} P_{P l}(1-\mathrm{H})+a_{\mathrm{R}} P_{\mathrm{R}} \mathrm{H}+\mathrm{C}_{\mathrm{Hb}} \mathrm{S} \cdot \mathrm{H}
$$

where $P_{b}$ is the total oxygen partial pressure in blood, and are the oxygen solubility constants in plasma and RBC fluids, respectively, $P_{P l}$ and $P_{R}$ are the oxygen partial pressures in plasma and RBC fluids, respectively, $H$ is the hematocrit, $C_{H b}$ is the $\mathrm{O}_{2}$-binding capacity of $\mathrm{Hb}$, and $\mathrm{S}$ is the hemoglobin saturation fraction (described in detail in the Appendix).

Oxygen transport in the blood can be determined by taking the partial derivative of Equation 2 with respect to time, $t$, and a spatial direction, $x$. Here, these equations are presented for blood components: plasma (Equation 3) and RBCs (Equation 4).

$$
\begin{aligned}
& (1-H) \frac{\partial \alpha_{P P} P_{P l}}{\partial t}+u_{b}(1-H) \frac{\partial \alpha_{P P} P_{P l}}{\partial x}=R_{R-P L}-j_{P L-T} \\
& H \frac{\partial\left(a_{R} P_{R}+C_{H b} S\right)}{\partial t}+u_{b} \cdot H \frac{\partial\left(\alpha_{R} P_{R}+C_{H b} S\right)}{\partial x}=-R_{R-P L}
\end{aligned}
$$

where $u_{b}$ is the blood velocity, $R_{R-P L}$ is a reaction term representing the plasma-RBC oxygen exchange rate and $j_{P L-T}$ is a flux density term representing oxygen exchange between plasma and tissue (subscript $t_{P L-T}$ ). Assuming that the oxygen partial pressure in blood plasma $\left(P_{P l}\right)$ and RBC fluids $\left(P_{R}\right)$ are in equilibrium, $P_{R}=P_{P l}$, we can combine Equation 3 and Equation to obtain a single equation for characterizing total oxygen transport in blood:

$$
\left(\alpha_{b} \frac{\partial P_{b}}{\partial t}+H \cdot C_{H b} \frac{\partial S}{\partial t}\right)+U_{b} \cdot\left(\alpha_{b} \frac{\partial P_{b}}{\partial x}+H \cdot C_{H b} \frac{\partial S}{\partial t}\right)=-J_{B T}
$$

where $j_{B T}$ is the blood-tissue oxygen flux density (equivalent to $j_{P L-T}$ ) and. The subscript $b$ included with parameters $a, u$, and $P$ indicates these parameters are associated with blood. Further homogenization, integration over the blood compartment volume, and simplification of Equation 5 yields the final working equation for the time-dependent partial pressure of $\mathrm{O}_{2}$ in blood. The total oxygen partial pressure is solved in each blood compartment, $j$, as follows:

$$
\left.\frac{\underline{d P_{i}}}{\underline{d t}}=\frac{1}{V_{j}} \frac{J_{B, j}}{\left[\left(a_{b}+H \cdot C_{H b} \frac{\left.n \cdot\left(P_{50}^{n}+P_{j}^{n}\right)^{n}\right)}{\left(P_{50}\right)}\right)\right.} Q_{j}\left(P_{j}-P_{0}\right)\right]
$$


where $Q_{j}$ is the volumetric flow rate of blood through blood compartment $j, P_{0}$ is the oxygen partial pressure entering the ocular vasculature (assumed equivalent to systemic oxygen partial pressure), $V_{j}$ is the volume of blood compartment $j$, and $J_{B T}$ is the diffusive flux between the blood compartment and surrounding tissue compartment. The subscript $j$ represents a specific vascular compartment (i.e., SVP or choriocapillaris). Full derivation of the final working equation is provided in the Appendix. Blood-tissue oxygen flux is given by:

$$
J_{B T, j}=K_{b t, j} \cdot A_{b t, j}\left(a_{t} P_{i}-\alpha_{b} P_{j}\right)
$$

where $A_{b t}$ represents the surface area of the vascular system and $K_{b t}$ is oxygen blood capillary permeability. The subscript $i$ represents a specific tissue compartment (i.e., NFL or choroid). Permeability values for this model are calculated based on diffusivity and diffusion distance (one-half of the retinal layer thickness or one-half of the average diameter of the vascular system):

$$
K_{b t, i}=\frac{1}{\frac{l_{i}}{2 D_{i}}+\frac{l_{i+1}}{2 D_{i+1}}} \quad, \quad K_{b t, i}=\frac{1}{\frac{l_{i}}{2 D_{i}}+\frac{l_{i+1}}{2 D_{i+1}}}
$$

where $D$ is the diffusion coefficient, lis the respective compartmenthalfthickness, and $r$ is the vascular-specific average radius. Inter-tissue permeability $\left(K_{t t, i}\right)$ is calculated similarly, and the subscript $i+1$ represents the adjacent tissue compartment. The subscript $t t$ or $T T$ indicate the parameter is tissue-tissue or inter-tissue related. Note that Equation EQ 6 is applied to each blood compartment separately.

\subsubsection{Perfused tissue oxygen transport}

Oxygen transport in perfused tissues is characterized by diffusive flux between blood and tissue compartments, as well as between adjacent tissue compartments. The blood-tissue diffusive flux for perfused tissues can be obtained by mass balance from the blood oxygen transport equation and combined with the inter-tissue diffusive flux to determine the time-dependent change in oxygen in a perfused tissue compartment, which is given by:

$$
a_{t} \cdot V_{i} \frac{d P_{\mathrm{i}}}{d t}=J_{B T, \mathrm{j}}+J_{T T, \mathrm{i}}-R_{m e t, i} \cdot V_{i}
$$

where $R_{\text {met, } i}$ is a reaction term representing oxygen metabolism in tissuecompartment $i$, and $J_{T T, i}$ represents the net inter-tissue diffusive flux for tissue compartment $i$, given by:

$$
J_{T T, i}=K_{t t, i_{i} i+1} \cdot A_{t t, i} \cdot a_{t}\left(P_{i+1}-P_{i}\right)-K_{t t, i-1 \_i} \cdot A_{t t, i} \cdot a_{t}\left(P_{i}-P_{i-1}\right)
$$


where $A_{t t, i}$ is the interfacial surface area (assumed equivalent to the retinal surface area).

\subsubsection{Non-perfused tissue oxygen transport}

Some tissue compartments in the posterior eye model are not perfused and rely solely on diffusive flux between tissue compartments to characterize the time-dependent change in oxygen partial pressure, given by:

$$
\alpha_{t} \cdot V_{i} \frac{d P_{i}}{d t}=J_{T T, i}-R_{m e t, i} \cdot V_{i}
$$

\subsubsection{Ocular oxygen metabolism}

Retinal cells are highly metabolically active, and as such, metabolism is a contributing factor to oxygen distribution in the posterior eye. However, oxygen metabolism in the vitreous, ${ }^{71} \mathrm{ONL},{ }^{72}$ and $\mathrm{RPE}^{73}$ are reportedly negligible, and $\mathrm{O}_{2}$ metabolism, $R_{02}$, is set to zero.

Michaelis-Menten (MM) type equations are used to characterize oxygen metabolism for the inner and outer retina and the choroid:

$$
R_{m e t, i}=a_{t} \frac{V_{\text {max,i }} \cdot P_{t, i}}{K_{m, i}+P_{t, 1}}
$$

where $i$ represents a specific tissue layer or region (i.e., inner or outer retina, Fig. 2), $R$ is the region-specific metabolic reaction rate, and $V_{\max }$ and $K_{m}$ are MM constants (specific to inner, outer, and choroid segments). Species-specific MM constants used in our simulations are shown in Table 5. Oxygen metabolism in the choroid was assumed to be the same as that in the sclera.

Table 5. Region and species-specific Michaelis-Menten constants for oxygen metabolism in the posterior eye

\begin{tabular}{|l|l|l|l|l|}
\hline \multirow{2}{*}{ Region } & \multicolumn{2}{|l|}{ Rabbit } & \multicolumn{2}{l|}{ Human/Mouse } \\
\cline { 2 - 5 } & $\begin{array}{l}\text { Vmax } \\
(\mathbf{m m H g} / \mathbf{s})\end{array}$ & $\mathbf{K m}^{\star}(\mathbf{m m H g})$ & $\begin{array}{l}\text { Vmax } \\
(\mathbf{m m H g} / \mathbf{s})\end{array}$ & $\mathbf{K m}(\mathbf{m m H g})$ \\
\hline Inner retina & 8 & 2 & 2673 & 273 \\
\hline Outer retina & 40 & 2 & 9073 & 273 \\
\hline Choroid & 1 & 1 & $0.1^{\star}$ & $1^{\star}$ \\
\hline${ }^{\star}$ Estimated & \multicolumn{3}{|l}{} & \\
\hline
\end{tabular}




\subsubsection{Linking nitric oxide production and oxygen metabolism}

Nitric oxide (NO) is a gaseous compound, which in mammals acts as a signaling molecule and is involved in numerous physiological and pathological processes. NO has been shown to regulate oxygen consumption in various species, ${ }^{74}$ particularly within the cardiovascular system. Additionally, NO plays a vital role in the synthesis of cyclic guanosine monophosphate (cGMP), a compound which is associated with autoregulation of ocular vasculature and has been linked to alteration of intraocular pressure.

\subsubsection{NO blood transport}

NO transport in the vasculature is characterized by blood-tissue diffusive flux and perfusion, similar to oxygen; however, an additional expression characterizing NO scavenging must also be considered. In blood, NO is scavenged by hemoglobin. The NO transport equation for blood compartments is given by:

$$
V_{j} \frac{d C_{N O, j}}{d t}=J_{N O_{-} B T, j}-\lambda_{b} \cdot C_{N O, j} \cdot V_{j}-Q_{j} \cdot\left(C_{N O, j}-0\right)
$$

where $C_{N O, j}$ is the NO blood concentration in vascular compartment $j, J_{N O_{B} B T, j}$ represents the blood-tissue diffusive flux for blood compartment $j$, and $\lambda_{b}$ is the NO scavenging rate in blood. Our model assumes that NO is produced in the blood compartment and that the NO content in the supplying arterial blood is negligible (zero value in the convective term of Equation $13 \mathrm{EQ} \mathrm{13).} \mathrm{The} \mathrm{NO} \mathrm{blood-tissue}$ diffusive flux is given by:

$$
J_{N O \_B T, j}=K_{N O \_b t, j} \cdot A_{b t, j}\left(C_{N O, j}-C_{N O, i}\right)
$$

where $K_{N o \_b t, j}$ is the NO blood-tissue permeability, and $C_{N O, i}$ is the NO tissue concentration in compartment $i$.

\subsubsection{2. $\mathrm{O}_{2}$ metabolism}

Lamkin-Kennard et al. developed and validated a model for characterizing oxygen metabolism as a function of NO concentration. ${ }^{74}$ The reaction rate equation for oxygen is modified to:

$$
R_{m e t, i}=\frac{V_{\text {max }, i} \cdot P_{i}}{K_{m, i}\left(1+\frac{C_{\mathrm{No}, i}}{0.027}\right)+P_{i}}
$$

where $C_{N O}$ is the NO concentration in tissue compartment $i$. Oxygen transport equations remain unchanged. Oxygen metabolism constants were calibrated on the data used for comparison (human, ${ }^{75}$ mouse, ${ }^{76}$ rabbit $^{77}$ ) to account for NO inclusion in the model (Table 6). 
Table 6. Calibrated oxygen Michaelis-Menten metabolism constants for inclusion of nitric oxide production in rabbits

\begin{tabular}{|l|l|l|}
\hline Region & Vmax (units) & Km (units) \\
\hline Inner retina & $6.15 \mathrm{E}-4(\mathrm{mmHg} / \mathrm{s})$ & $2(\mathrm{mmHg})$ \\
\hline Outer retina & $10.9 \mathrm{E}-4(\mathrm{mmHg} / \mathrm{s})$ & $2(\mathrm{mmHg})$ \\
\hline Choroid & $6.5 \mathrm{E}-5(\mathrm{mmHg} / \mathrm{s})$ & $2(\mathrm{mmHg})$ \\
\hline
\end{tabular}

\subsubsection{NO perfused tissue transport}

In the same way that oxygen is exchanged between blood and tissue, NO is also transported from the vasculature to surrounding tissue by diffusive flux. The mass transport equation for $\mathrm{NO}$ in vascularized tissue compartments is described by:

$$
V_{i} \frac{d C_{N O, i}}{d t}=J_{N O_{-} T T, i}-J_{N_{B}, j}-\lambda_{t} \cdot C_{N O, i} \cdot V_{i}
$$

where $J_{\text {NO_TT,i }}$ represents the net diffusive flux between the perfused tissue compartment $i$ and adjacent tissue compartments ( $i+1$ and/or $i-1)$ and $\lambda_{t}$ is the NO scavenging rate in tissue. Net diffusional flux between adjacent tissue compartments is given by:

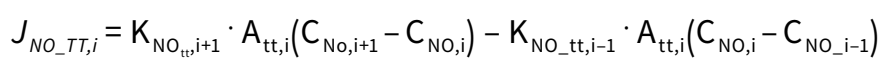

Note that NO permeability values are calculated similarly to the method used for oxygen.

\subsubsection{NO nonperfused tissue transport}

NO is further exchanged with nonperfused ocular tissues by diffusion. The mass transport equation for NO in nonvascularized tissue compartments is described by:

$$
V_{i} \frac{d C_{t_{-} N O, i}}{d t}=J_{N O_{-} T T, i}-\lambda_{t} \cdot C_{N O, i} \cdot V_{i}
$$

\subsubsection{Numerical methods}

The final set of $\mathrm{O}_{2}$ and $\mathrm{NO}$ transport equations in the blood and tissue compartments are described by a set of ordinary differential equations (ODEs). The final set of ODEs are provided in the supplementary material by species. The dependent variables for this system of equations includes: i) oxygen partial pressures in all tissues $\left(P_{i}\right)$, ii) oxygen partial pressures in all vasculature $\left(P_{j}\right)$, iii) NO concentration in all tissues $\left(C_{N O, i}\right)$, and iv) NO concentration in all vasculature $\left(C_{N O, j}\right)$. The resultant 
system of ODEs is solved using in-house developed software, Computational Biology (CoBi) tools. CoBi's numerical methods for solving systems of stiff ODEs has been previously reported in detail. ${ }^{78} \mathrm{CoBi}$ tools are available at http://medicalavatars.cfdrc.com/index.php/cobi-tools/.

\section{Results}

The time-dependent change in oxygen partial pressure and NO concentration in posterior ocular tissues and vasculature for human, rabbit, and mouse were simulated. Most model input parameters were obtained from literature and are provided in Table 7.

Estimated parameters were fit using the experimental data in Figure 4. For all simulations, oxygen partial pressure in all tissues and vascular compartments was initially set to 0 , with the exception of the vitreous humor. Vitreous humor concentration in all simulations and species was set to a constant value observed in the experimental data sets obtained from literature. For those simulations involving oxygen-nitrogen interplay, NO concentration in all tissues and vascular compartments was initially set to 0 .

Despite the fact that time-dependent simulations were performed, steady state $\mathrm{O}_{2}$ and $\mathrm{NO}$ values for each tissue were required for comparison with experimental data. While minimal model calibration was required, some parameter values were not available in literature. Specifically, the metabolic parameters for the $\mathrm{O}_{2}-\mathrm{NO}$ rabbit model had to be calibrated to fit the simulated data to the compared experimental values. Best fit metabolism values were determined using open-source non-gradient-based optimization methods, DAKOTA. ${ }^{99}$

\subsection{Oxygenation of the posterior eye}

Spatial distribution of oxygen in the posterior eye (as a function of retinal distance from the vitreous) was evaluated after allowing simulation to reach steady state. The model was validated by comparing simulated oxygen partial pressure profiles for mouse, human, and rabbit with experimental data (Fig. 4). For the mouse and the rabbit, the retinal distance is nondimensionalized by the vitreous to choroid thickness. Experimental data for comparisons were obtained from literature (human $^{75}$, mouse $^{76}$, rabbit $^{77}$ ).

Oxygen tension in the middle of the mouse and human retinas is reportedly close to zero under normal physiologic conditions, ${ }^{75,82,100}$ and is most likely due to the high oxidative demands of the photoreceptors and dependence on diffusive oxygen transport. ${ }^{48,101,102}$ We capture this trend in our simulations as well. Overall, simulation agrees well with experimental data profiles for all species (Fig. 4). 
Table 7. Model input parameters

\begin{tabular}{|c|c|c|}
\hline Symbol & Description & Value (units) \\
\hline \multicolumn{3}{|c|}{ Compound properties } \\
\hline $\mathbf{D}_{\mathrm{t}}$ & $\mathrm{O}_{2}$ Diffusivity in retinal tissue & $1.97 \times 10^{-9} \mathrm{~m} 2 / \mathrm{s}^{79}$ \\
\hline $\mathbf{D}_{\mathrm{b}}$ & $\mathrm{O}_{2}$ Diffusivity in blood & $2.18 \times 10^{-9} \mathrm{~m} 2 / \mathrm{s}^{80}$ \\
\hline $\mathbf{D}_{\mathrm{NO}}$ & NO Diffusivity in tissue & $3.30 \times 10^{-9} \mathrm{~m} 2 / \mathrm{s}^{81}$ \\
\hline $\boldsymbol{a}_{\mathrm{t}}$ & $\mathrm{O}_{2}$ Solubility in tissue & $2.40 \times 10^{-5} \mathrm{~mL} \mathrm{O}_{2} / \mathrm{mL} / \mathrm{mmHg}^{82}$ \\
\hline $\boldsymbol{\alpha}_{R}$ & $\mathrm{O}_{2}$ Solubility in RBC fluid & $3.38 \times 10^{-5} \mathrm{~mL} \mathrm{O}_{2} / \mathrm{mL} / \mathrm{mmHg}^{68}$ \\
\hline $\boldsymbol{\alpha}_{\mathrm{Pl}}$ & $\mathrm{O}_{2}$ Solubility in plasma & $2.82 \times 10^{-5} \mathrm{~mL} \mathrm{O}_{2} / \mathrm{mL} / \mathrm{mmHg}^{68}$ \\
\hline \multicolumn{3}{|c|}{ Physiological parameters } \\
\hline H & Blood hematocrit & $\begin{array}{l}\text { Human: } 0.45^{83} \\
\text { Mouse: } 0.45^{84} \\
\text { Rabbit: } 0.37^{85,86} \\
\end{array}$ \\
\hline $\mathbf{C}_{\mathrm{Hb}}$ & $\begin{array}{l}\text { Carrying capacity of } \\
\text { hemoglobin }\end{array}$ & 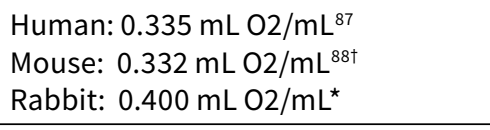 \\
\hline $\mathbf{P}_{0}$ & $\begin{array}{l}\text { O2 partial pressure entering } \\
\text { ocular vasculature }\end{array}$ & $\begin{array}{l}\text { Human: } 89 \mathrm{mmHg}^{89} \\
\text { Mouse: (retina) } 37 \mathrm{mmHg}^{90} \\
\quad \text { (choriocapillaris) } 47 \mathrm{mmHg}^{91} \\
\text { Rabbit: } 73 \mathrm{mmHg}{ }^{92}\end{array}$ \\
\hline $\mathbf{Q}$ & Blood volumetric flow rate & See Table 2 \\
\hline$\lambda_{\mathrm{b}}$ & NO scavenging in blood by $\mathrm{Hb}$ & $1001 / \mathrm{s}^{93}$ \\
\hline$\lambda_{\mathrm{t}}$ & NO scavenging in tissue by $\mathrm{SGC}$ & $11 / \mathrm{s}^{94-96}$ \\
\hline $\mathbf{P}_{50}$ & $\begin{array}{l}\mathrm{O}_{2} \text { partial pressure in blood at } \\
\text { half hemoglobin saturation }\end{array}$ & $\begin{array}{l}\text { Human: } 26.6 \mathrm{mmHg}^{87} \\
\text { Mouse: } 41.5 \mathrm{mmHg}{ }^{97} \\
\text { Rabbit: } 30.0 \mathrm{mmHg} 98\end{array}$ \\
\hline n & Hill exponent & 2.787 \\
\hline
\end{tabular}

$\mathrm{O}_{2}$ : oxygen; No: nitric oxide; RBC: red blood cells; Hb: hemoglobin; sGC: soluble guanylyl cyclase

${ }^{\dagger}$ Determined from ratio of Hufner's factor for human and mouse.

Estimated. 

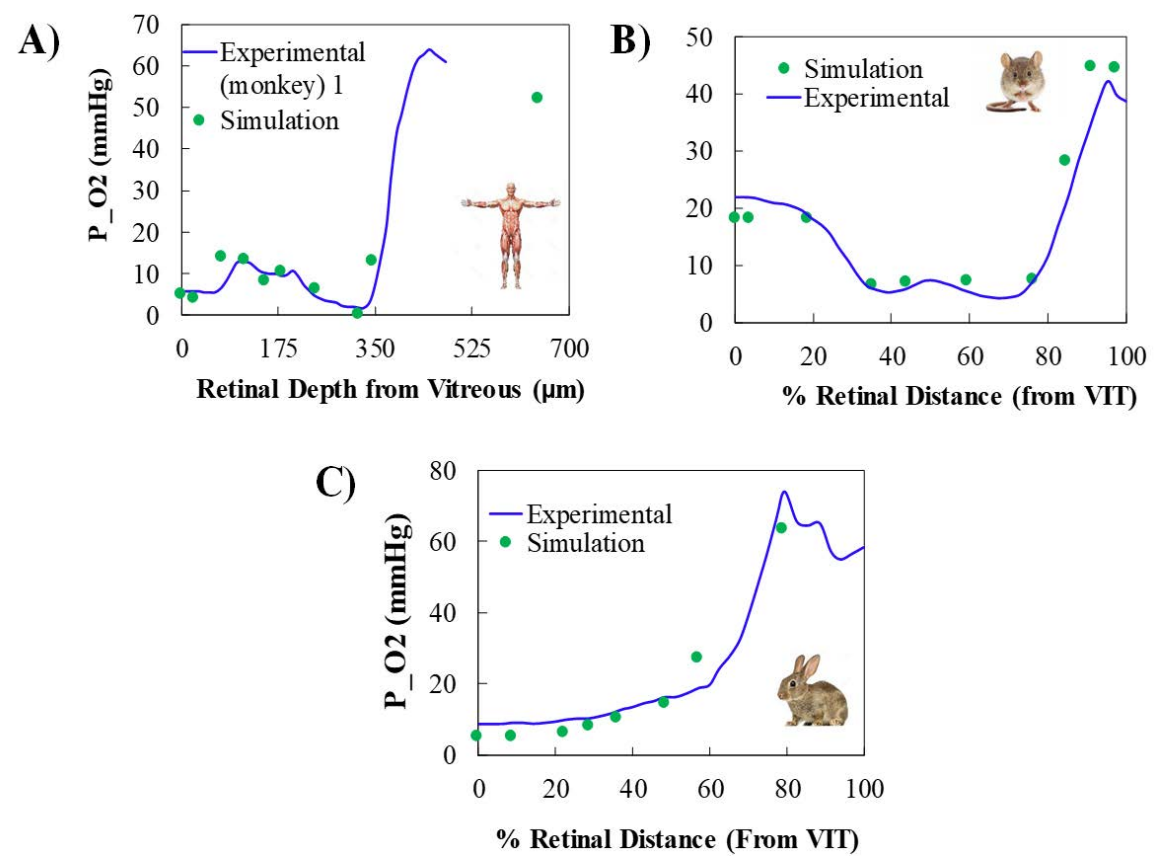

Fig. 4. Comparison of simulated oxygen partial pressure pharmacokinetic profiles with experimental data for $(A)$ human, $(B)$ mouse, and $(C)$ rabbit.

\subsection{Oxygenation of the posterior eye with nitric oxide-dependent metabolism} The impact of the addition of a NO concentration component to oxygen metabolism on oxygen distribution in the posterior segment was evaluated. Figure 5a demonstrates that model inclusion of the NO component in oxygen metabolism improved results when compared with experimental data and simulation of oxygen alone. Steady state concentrations of NO were achieved relatively rapidly in the model (Fig. 5b). Oxygen partial pressure in tissue and vascular compartments also reached steady state values in a similarly rapid manner. Oxygen-only simulations also reached steady state rapidly, but not as quickly as those including NO considerations. The steady state values for ocular tissue of approximately $0.2 \mu \mathrm{M}$ or $200 \mathrm{nM}$ are in good agreement with published estimates of $295 \mathrm{nM}$ in the rabbit vasculature. ${ }^{103}$ 


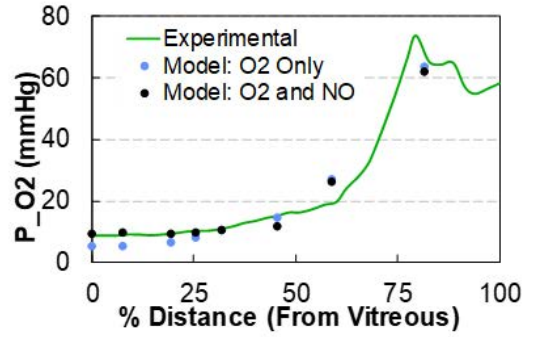

(a)

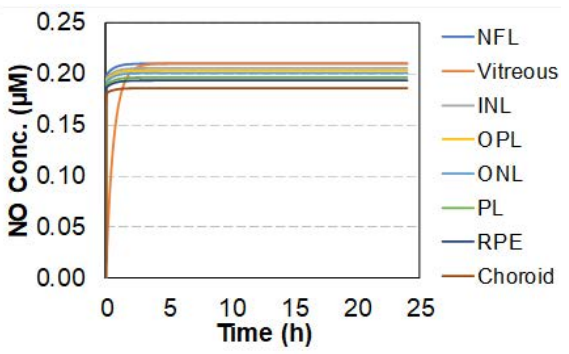

(b)

Fig. 5. Simulation results from the rabbit posterior eye model for $(a)$ spatial distribution of oxygen in the posterior eye and $(b)$ steady state NO concentrations matched well with experimental data and expected values, respectively.

\section{Discussion}

Translation of results from animal models to humans has always been challenging. This continues to hold true in ocular research and ophthalmic drug development. Interspecies variation in ocular anatomy and physiology leads to very different compound distribution profiles, and thus, varied degrees of PD effects. Predictive computational models have the potential to explain and demonstrate interspecies differences in compound distribution in the retinal region and the corresponding PD effects, thereby enhancing translational capabilities. Such models must highlight anatomical and physiological differences for physiologically based scaling to reduce model calibration and improve predictability. A unified mathematical modeling framework that enables interspecies translation is currently lacking.

A number of mathematical models have been developed to describe retinal oxygenation. ${ }^{104}$ These models typically evaluate oxygen profiles at steady state and in one dimension across the retinal thickness, similar to our approach. Many retinal oxygenation models lump the inner and outer retinal segments together, often choosing to focus on the outer retina to avoid consideration of vascularization. But with the important role the vasculature plays in retinal oxygenation, we felt a vascular component was necessary. Further, current models use a single vascular set for the entire posterior eye. The present model involves a topological vascular layout in the retina and in the choroid. In an attempt to maintain physiological relevance for the vasculature, we use a permeability-limited equation for blood-tissue oxygen exchange based on the exchange surface area and compound diffusivity. In contrast, current retinal oxygenation models use first-order kinetics with a calibrated constant to represent elimination or supply by the vasculature, lacking physiological relevance. The retinal models available in literature focus 
either on species with vascularized retinas (i.e., mouse or human) or on species with an avascular retina (i.e., rabbit). To the authors' knowledge, this is the first presentation of a single framework for modeling both types of retinas based solely on anatomical and physiological differences.

This paper presents a framework for modeling interspecies variation in oxygenation through physiologically based scaling of posterior eye anatomy and species-specific placement of vascular structures. This framework significantly reduces the need for model calibration by using species-specific anatomical and physiological parameters, as well as compound-specific physicochemical properties. Simulation profiles for retinal oxygen partial pressure along the posterior eye depth from oxygen only simulations were in good agreement with experimental data for all three species. The majority of model parameters, including anatomy, physiological flow rates and metabolic constants, were obtained from literature. Minimal parameter calibration was needed to fit the model. Fitted parameters were primarily associated with vascular surface area and metabolic constants in some species. The MM constant, $\mathrm{Km}$, is assumed to be species independent. The oxygen consumption constants for mouse and human were assumed to be identical, but this assumption needs to be validated. The oxygen consumption constants in rabbit were calibrated due to lack of data, and thus also need validating. However, significantly lower values for the oxygen consumption constants in rabbits as compared with humans/mice is a good assumption considering the avascular nature of the rabbit retina.

Adequate oxygenation plays an important role in ocular health. Clear correlations between ocular hemodynamics and various diseases (i.e., glaucoma, retinopathy, etc.) have been demonstrated. ${ }^{72,105,106}$ Oxygen also plays a role in the production of cGMP via the soluble guanylyl cyclase (sGC)-mediated pathway (NOSGC-cGMP), as NO production rates are directly impacted by the percent oxygen present. ${ }^{107}$ Increased cGMP production in vascular smooth muscle cells has been shown to induce vasorelaxation. Due to the impact NO has on oxygen metabolism and the importance of both in major PD effect pathways, NO transport and effect on oxygen metabolism was integrated into the rabbit retinal oxygenation model. Simulated NO profiles were similar for all rabbit retinal tissues. These steady state values matched well with reported physiological values. The fit of simulated oxygen profiles along the retinal depth was slightly improved by the inclusion of NO and its impact on oxygen metabolism. The metabolic parameter Vmax had to be calibrated to accommodate the inclusion of NO. These values should be validated experimentally.

Our framework is currently limited to posterior eye applications enabling either systemic drug delivery or localized injections (periocular, scleral, or intravitreal). While the retinal segment is resolved in $1 \mathrm{D}$ in the radial direction, the vitreous body, much larger by comparison, is not resolved at all, but represented by a single compartment. While this may not be limiting for the current case, intravit- 
real drug injections may require high-resolution geometry. The model currently neglects convective drug transport due to fluid flow from the ciliary body across the retina. Initially, convective contributions were also considered in the present model; however, after model evaluation both with and without retinal convection, we found that convective contributions were negligible, and thus were not included in any of our models. In the future, the impact of retinal flow should be investigated across species. At present, flow velocity data for all species in this paper is limited. Finally, the estimation of vascular surface areas requires validation for all species to improve model strength.

This framework has the potential for advancement in multiple directions. While we use oxygen profiles and local steady state NO concentrations to validate the model, this framework could also be used to evaluate PK profiles for drugs used to treat posterior eye diseases. The translational power of this model could be extremely valuable in helping determine drug formulations, dosing amounts, and regimens. Secondly, the expansion of this model to include the anterior segment of the eye with increased vitreous body resolution would enable evaluation of topical application. Topical application is the most commonly prescribed method for treating ocular symptoms/disease; however, less than $5 \%$ of topically administered drugs reach postcorneal ocular targets. Our posterior eye model could tie in easily with some of the currently available compartmental anterior eye models. Lastly, the incorporation of PD models would significantly advance the translational power of this framework. With oxygen and NO models already in place, a logical next step would be incorporation of a model of the NO-sGC-cGMP pathway for physiologically based PK-PD modeling.

\section{Conclusions}

Oxygen is a critical metabolite for preserving retinal function in humans, and retinal hypoxia is considered to be a factor in many retinal diseases. Better understanding the oxygen transport and metabolism in different retinal layers may help in the development of improved therapeutic intervention strategies. This paper presents a physiologically based mathematical model of oxygen and nitric oxide distribution in the posterior eyes of mouse, rabbit and human, accounting for species-specific anatomical and physiological differences. The predicted profiles for retinal oxygen partial pressure along the posterior eye depth are in good agreement with experimental data for all three species. Minimal parameter calibration was needed to fit the model. Fitted parameters were primarily associated with vascular surface area and metabolic constants in some species.

The detailed model of oxygen transport in the blood, distribution of choroid/retinal tissues, metabolism in optically active retinal layers, and NO-induced vasoregulation provide a foundation for evaluation of various pharmacological interventions. 
The present model has been designed as a pharmacodynamics module in the integrated PBPK/PD simulation framework ${ }^{108}$ to evaluate the variations of retinal oxygenation in response to various drugs, formulations, administration protocols, and treatment plans. Moreover, the common ocular PBPK/PD model validated on mouse and rabbit data could enable animal-to-human translation, a critical step in the drug development process.

\section{Declarations}

\section{Ethics approval and consent to participate}

Not applicable.

Competing interests

None to declare

\section{Funding}

Funding for this work was provided by Merck \& Co. Rahway, NJ USA

\section{Acknowledgements}

None to declare 


\section{References}

1. Pascolini D, Mariotti SP. Global estimates of visual impairment: 2010. Br J Ophthalmol. 2012 May;96(5):614-8. Epub 2011 Dec 1. PMID: 22133988. https://doi.org/10.1136/bjophthalmol-2011-300539

2. Flaxman SR, Bourne RRA, Resnikoff S, Ackland P, Braithwaite T, Cicinelli MV, Das A, Jonas JB, Keeffe J, Kempen JH, Leasher J, Limburg H, Naidoo K, Pesudovs K, Silvester A, Stevens GA, Tahhan N, Wong TY, Taylor HR; Vision Loss Expert Group of the Global Burden of Disease Study. Global causes of blindness and distance vision impairment 1990-2020: a systematic review and meta-analysis. Lancet Glob Health. 2017 Dec;5(12):e1221-e1234. Epub 2017 Oct 11. PMID: 29032195. https://doi.org/10.1016/ S2214-109X(17)30393-5

3. Urtti A, Salminen L. Minimizing systemic absorption of topically administered ophthalmic drugs. Surv Ophthalmol. 1993 May-Jun;37(6):435-56. PMID: 8100087. https://doi.org/10.1016/00396257(93)90141-s

4. Agrahari V, Mandal A, Agrahari V, Trinh HM, Joseph M, Ray A, Hadji H, Mitra R, Pal D, Mitra AK. A comprehensive insight on ocular pharmacokinetics. Drug Deliv Transl Res. 2016 Dec;6(6):735-754. PMID: 27798766; PMCID: PMC5319401. https://doi.org/10.1007/s13346-016-0339-2

5. Gaudana R, Ananthula HK, Parenky A, Mitra AK. Ocular drug delivery. AAPS J. 2010 Sep;12(3):348-60. Epub 2010 May 1. PMID: 20437123; PMCID: PMC2895432. https://doi.org/10.1208/s12248-010-9183-3

6. Patel A, Cholkar K, Agrahari V, Mitra AK. Ocular drug delivery systems: An overview. World J Pharmacol. 2013;2(2):47-64. PMID: 25590022; PMCID: PMC4289909. https://doi.org/10.5497/wjp.v2.i2.47

7. Ali J, Fazil M, Qumbar M, Khan N, Ali A. Colloidal drug delivery system: amplify the ocular delivery. Drug Deliv. 2016;23(3):710-26. Epub 2014 Jun 3. PMID: 24892625. https://doi.org/10.3109/10717544 .2014 .923065

8. Joseph RR, Venkatraman SS. Drug delivery to the eye: what benefits do nanocarriers offer? Nanomedicine (Lond). 2017 Mar;12(6):683-702. Epub 2017 Feb 10. PMID: 28186436. https://doi.org/10.2217/ nnm-2016-0379

9. Evangelho K, Mastronardi CA, de-la-Torre A. Experimental Models of Glaucoma: A Powerful Translational Tool for the Future Development of New Therapies for Glaucoma in Humans-A Review of the Literature. Medicina (Kaunas). 2019 Jun 17;55(6):280. PMID: 31212881; PMCID: PMC6630440. https:// doi.org/10.3390/medicina55060280

10. Krebs MP, Collin GB, Hicks WL, Yu M, Charette JR, Shi LY, Wang J, Naggert JK, Peachey NS, Nishina PM. Mouse models of human ocular disease for translational research. PLoS One. 2017 Aug 31;12(8):e0183837. PMID: 28859131; PMCID: PMC5578669. https://doi.org/10.1371/journal. pone. 0183837

11. Mustari MJ. Nonhuman Primate Studies to Advance Vision Science and Prevent Blindness. ILAR J. 2017 Dec 1;58(2):216-225. PMID: 28575309; PMCID: PMC5886335. https://doi.org/10.1093/ilar/ilx009

12. Carvalho C, Gaspar A, Knight A, Vicente L. Ethical and Scientific Pitfalls Concerning Laboratory Research with Non-Human Primates, and Possible Solutions. Animals (Basel). 2018 Dec 29;9(1):12. PMID: 30597951; PMCID: PMC6356609. https://doi.org/10.3390/ani9010012

13. Manning FJ, Bond EC, Berns KI. The Washington Regional Primate Research Center. In: Resource Sharing in Biomedical Research. National Academies Press; 1996. 
14. Del Amo EM, Urtti A. Rabbit as an animal model for intravitreal pharmacokinetics: Clinical predictability and quality of the published data. Exp Eye Res. 2015 Aug;137:111-24. Epub 2015 May 12. Erratum in: Exp Eye Res. 2018 Jan 31;169:60. PMID: 25975234. https://doi.org/10.1016/j.exer.2015.05.003

15. Ahmed I, Patton TF. Disposition of timolol and inulin in the rabbit eye following corneal versus non-corneal absorption. Int J Pharm. 1987 Aug 1;38(1-3):9-21.

16. Barbazetto IA, Liang J, Chang S, Zheng L, Spector A, Dillon JP. Oxygen tension in the rabbit lens and vitreous before and after vitrectomy. Exp Eye Res. 2004 May;78(5):917-24. PMID: 15051473. https:// doi.org/10.1016/j.exer.2004.01.003

17. Carcaboso AM, Bramuglia GF, Chantada GL, Fandiño AC, Chiappetta DA, de Davila MT, Rubio MC, Abramson DH. Topotecan vitreous levels after periocular or intravenous delivery in rabbits: an alternative for retinoblastoma chemotherapy. Invest Ophthalmol Vis Sci. 2007 Aug;48(8):3761-7. PMID: 17652749. https://doi.org/10.1167/iovs.06-1152

18. Gwon A. The Rabbit in Cataract/IOL Surgery. In: Tsonis PA, (editor). Animal Models in Eye Research Academic Press; 2008. pp. 184-204. https://doi.org/10.1016/B978-0-12-374169-1.00013-8

19. Akhtar A. The flaws and human harms of animal experimentation. Camb Q Healthc Ethics. 2015 Oct;24(4):407-19. PMID: 26364776; PMCID: PMC4594046. https://doi.org/10.1017/ S0963180115000079

20. Gawrylewski A. The Trouble with Animal Models. (2007) The Scientist Magazine. Available from: https://www.the-scientist.com/uncategorized/the-trouble-with-animal-models-46344

21. Cattaneo C, Maderna E, Rendinelli A, Gibelli D. Animal experimentation in forensic sciences: How far have we come? Forensic Sci Int. 2015 Sep;254:e29-35. Epub 2015 Jul 15. PMID: 26216717. https://doi. org/10.1016/j.forsciint.2015.06.024

22. Cohen L. Relationships between visual function and metabolism. Biochem Eye. 1965:36-50.

23. Wong-Riley MT. Energy metabolism of the visual system. Eye Brain. 2010;2:99-116. Epub 2010 Jul 22. PMID: 23226947; PMCID: PMC3515641. https://doi.org/10.2147/EB.S9078

24. Anderson B, Saltzman HA. Retinal oxygen utilization measured by hyperbaric blackout. Arch Ophthalmol. 1964 Dec 1;72(6):792-5.

25. Ames A 3rd. Energy requirements of CNS cells as related to their function and to their vulnerability to ischemia: a commentary based on studies on retina. Can J Physiol Pharmacol. 1992;70 Suppl:S15864. PMID: 1295666. https://doi.org/10.1139/y92-257

26. One Hour Optical. Retinal Disease, Problems, Treatments. What are Retinal Diseases? Available from: https://onehouroptical.com/eye-health/what-are-retinal-diseases

27. Najmanová E, Pluháček F, Botek M, Krejčí J, Jarošová J. Intraocular Pressure Response to ShortTerm Extreme Normobaric Hypoxia Exposure. Front Endocrinol (Lausanne). 2019 Jan 7;9:785. PMID: 30666235; PMCID: PMC6330315. https://doi.org/10.3389/fendo.2018.00785

28. Wójcik-Gryciuk A, Skup M, Waleszczyk WJ. Glaucoma -state of the art and perspectives on treatment. Restor Neurol Neurosci. 2016;34(1):107-23. PMID: 26684267; PMCID: PMC4927811. https://doi. org/10.3233/RNN-150599

29. Acharya R, Ng YE, Suri JS. Image modeling of the human eye. Artech House; 2008.

30. Gajraj R. A study of drug transport in the vitreous humor: effect of drug size; comparing micro-and macro-scale diffusion; assessing vitreous models; and obtaining in vivo data (Doctoral dissertation. 2012). 
31. Ferguson LR, Dominguez JM 2nd, Balaiya S, Grover S, Chalam KV. Retinal Thickness Normative Data in Wild-Type Mice Using Customized Miniature SD-OCT. PLoS One. 2013 Jun 27;8(6):e67265. PMID: 23826252; PMCID: PMC3695045. https://doi.org/10.1371/journal.pone.0067265

32. Faude F, Francke M, Makarov F, Schuck J, Gärtner U, Reichelt W, Wiedemann P, Wolburg H, Reichenbach A. Experimental retinal detachment causes widespread and multilayered degeneration in rabbit retina. J Neurocytol. 2001 May;30(5):379-90. PMID: 11951049. https://doi. org/10.1023/a:1015061525353

33. van Dijk HW, Verbraak FD, Kok PH, Garvin MK, Sonka M, Lee K, Devries JH, Michels RP, van Velthoven ME, Schlingemann RO, Abràmoff MD. Decreased retinal ganglion cell layer thickness in patients with type 1 diabetes. Invest Ophthalmol Vis Sci. 2010 Jul;51(7):3660-5. Epub 2010 Feb 3. PMID: 20130282; PMCID: PMC2904016. https://doi.org/10.1167/iovs.09-5041

34. Manning PJ. The Biology of the Laboratory Rabbit. Academic Press; 2014.

35. Ozkaya A, Alkin Z, Karakucuk Y, Karatas G, Fazil K, Gurkan Erdogan M, Perente I, Taskapili M. Thickness of the retinal photoreceptor outer segment layer in healthy volunteers and in patients with diabetes mellitus without retinopathy, diabetic retinopathy, or diabetic macular edema. Saudi J Ophthalmol. 2017 Apr-Jun;31(2):69-75. Epub 2017 Jan 4. PMID: 28559716; PMCID: PMC5436385. https://doi.org/10.1016/j.sjopt.2016.12.006

36. Terauchi G, Shinoda K, Matsumoto CS, Watanabe E, Matsumoto H, Mizota A. Recovery of photoreceptor inner and outer segment layer thickness after reattachment of rhegmatogenous retinal detachment. Br J Ophthalmol. 2015 Oct;99(10):1323-7. Epub 2015 Apr 3. PMID: 25841234. https://doi. org/10.1136/bjophthalmol-2014-306252

37. Mac Gabhann F, Demetriades AM, Deering T, Packer JD, Shah SM, Duh E, Campochiaro PA, Popel AS. Protein transport to choroid and retina following periocular injection: theoretical and experimental study. Ann Biomed Eng. 2007 Apr;35(4):615-30. Epub 2007 Feb 3. PMID: 17277991. https://doi. org/10.1007/s10439-006-9238-x

38. Karawya S, Said DG, Salaheldin MM, Zaky I. Impact of Intravitreal Injection of Bevacizumab (Avastin) on Rabbit's Choroid and Retina. Middle East Afr J Ophthalmol. 2008 Apr;15(2):67-72. PMID: 21346840; PMCID: PMC3038111. https://doi.org/10.4103/0974-9233.51995

39. Ko F, Foster PJ, Strouthidis NG, Shweikh Y, Yang Q, Reisman CA, Muthy ZA, Chakravarthy U, Lotery AJ, Keane PA, Tufail A, Grossi CM, Patel PJ; UK Biobank Eye \& Vision Consortium. Associations with Retinal Pigment Epithelium Thickness Measures in a Large Cohort: Results from the UK Biobank. Ophthalmology. 2017 Jan;124(1):105-117. Epub 2016 Oct 6. PMID: 27720551. https://doi.org/10.1016/j. ophtha.2016.07.033

40. Prince JH, Diesem CD, Eglitis I, Ruskell GL. Anatomy and histology of the eye and orbit in domestic animals. 1960.

41. Margolis R, Spaide RF. A pilot study of enhanced depth imaging optical coherence tomography of the choroid in normal eyes. Am J Ophthalmol. 2009 May;147(5):811-5. Epub 2009 Feb 20. PMID: 19232559. https://doi.org/10.1016/j.ajo.2008.12.008

42. Manjunath V, Taha M, Fujimoto JG, Duker JS. Choroidal thickness in normal eyes measured using Cirrus HD optical coherence tomography. Am J Ophthalmol. 2010 Sep;150(3):325-329.e1. Epub 2010 Jun 29. PMID: 20591395; PMCID: PMC2926223. https://doi.org/10.1016/j.ajo.2010.04.018 
43. Gargini C, Novelli E, Piano I, Biagioni M, Strettoi E. Pattern of retinal morphological and functional decay in a light-inducible, rhodopsin mutant mouse. Sci Rep. 2017 Jul 18;7(1):5730. PMID: 28720880; PMCID: PMC5516022. https://doi.org/10.1038/s41598-017-06045-x

44. Reichenbach A, Ziegert M, Schnitzer J, Pritz-Hohmeier S, Schaaf P, Schober W, Schneider H. Development of the rabbit retina. V. The question of 'columnar units'. Brain Res Dev Brain Res. 1994 May 13;79(1):72-84. PMID: 8070066. https://doi.org/10.1016/0165-3806(94)90050-7

45. Michels RG, Wilkinson CP, Rice TA. Retinal detachment. Mosby: St. Louis; 1990.

46. Nagra M, Gilmartin B, Thai NJ, Logan NS. Determination of retinal surface area. J Anat. 2017 Sep;231(3):319-324. Epub 2017 Jun 16. PMID: 28620965; PMCID: PMC5554828. https://doi. org/10.1111/joa.12641

47. Panda-Jonas S, Jonas JB, Jakobczyk M, Schneider U. Retinal photoreceptor count, retinal surface area, and optic disc size in normal human eyes. Ophthalmology. 1994 Mar;101(3):519-23. PMID: 8127572. https://doi.org/10.1016/s0161-6420(94)31305-4

48. Duong TQ, Pardue MT, Thulé PM, Olson DE, Cheng H, Nair G, Li Y, Kim M, Zhang X, Shen Q. Layer-specific anatomical, physiological and functional MRI of the retina. NMR Biomed. 2008 Nov;21(9):978-96. PMID: 18792422; PMCID: PMC2752861. https://doi.org/10.1002/nbm.1311

49. Hyvdrinen L. Vascular Structures of the Rabbit Retina. Acta Ophthalmol (Copenh.) 1967;45:852-861.

50. Muir ER, Rentería RC, Duong TQ. Reduced ocular blood flow as an early indicator of diabetic retinopathy in a mouse model of diabetes. Invest Ophthalmol Vis Sci. 2012 Sep 21;53(10):6488-94. PMID: 22915034; PMCID: PMC4045095. https://doi.org/10.1167/iovs.12-9758

51. Nilsson S, Alm, A. Determination of ocular blood flows with the microsphere method. In: Ocular Blood Flow. Springer; 2012. pp. 25-47.

52. Sebag J, Tang M, Brown S, Sadun AA, Charles MA. Effects of pentoxifylline on choroidal blood flow in nonproliferative diabetic retinopathy. Angiology. 1994 Jun;45(6):429-33. PMID: 8203768. https://doi. org/10.1177/000331979404500603

53. Feke GT, Tagawa H, Deupree DM, Goger DG, Sebag J, Weiter JJ. Blood flow in the normal human retina. Invest Ophthalmol Vis Sci. 1989 Jan;30(1):58-65. PMID: 2643588.

54. Campbell JP, Zhang M, Hwang TS, Bailey ST, Wilson DJ, Jia Y, Huang D. Detailed Vascular Anatomy of the Human Retina by Projection-Resolved Optical Coherence Tomography Angiography. Sci Rep. 2017 Feb 10;7:42201. PMID: 28186181; PMCID: PMC5301488. https://doi.org/10.1038/srep42201

55. Cerani A, Tetreault N, Menard C, Lapalme E, Patel C, Sitaras N, Beaudoin F, Leboeuf D, De Guire V, Binet F, Dejda A, Rezende FA, Miloudi K, Sapieha P. Neuron-derived semaphorin 3A is an early inducer of vascular permeability in diabetic retinopathy via neuropilin-1. Cell Metab. 2013 Oct 1;18(4):505-18. PMID: 24093675. https://doi.org/10.1016/j.cmet.2013.09.003

56. Sugano Y, Sekiryu T, Furuta M, Tomita R, Shintake H, Maehara H, Ojima A. Morphometrical evaluation of the choriocapillaris imaged by swept-source optical coherence tomography angiography. Clin Ophthalmol. 2018 Nov 5;12:2267-2276. PMID: 30464388; PMCID: PMC6223397. https://doi. org/10.2147/OPTH.S179634

57. Goto S, Onishi A, Misaki K, Yonemura S, Sugita S, Ito H, Ohigashi Y, Ema M, Sakaguchi H, Nishida K, Takahashi M. Neural retina-specific Aldh1a1 controls dorsal choroidal vascular development via Sox9 expression in retinal pigment epithelial cells. Elife. 2018 Apr 3;7:e32358. PMID: 29609731; PMCID: PMC5882243. https://doi.org/10.7554/eLife.32358 
58. Zhu Q, Xing X, Zhu M, Xiao H, Ma L, Chen L, Liang J, Yuan Y, Song E. A New Approach for the Segmentation of Three Distinct Retinal Capillary Plexuses Using Optical Coherence Tomography Angiography. Transl Vis Sci Technol. 2019 Jun 28;8(3):57. PMID: 31293812; PMCID: PMC6602150. https://doi. org/10.1167/tvst.8.3.57

59. Kim TH, Son T, Lu Y, Alam M, Yao X. Comparative Optical Coherence Tomography Angiography of Wild-Type and rd10 Mouse Retinas. Transl Vis Sci Technol. 2018 Dec 28;7(6):42. PMID: 30619662; PMCID: PMC6314228. https://doi.org/10.1167/tvst.7.6.42

60. Condren AB, Kumar A, Mettu P, Liang KJ, Zhao L, Tsai JY, Fariss RN, Wong WT. Perivascular mural cells of the mouse choroid demonstrate morphological diversity that is correlated to vasoregulatory function. PLoS One. 2013;8(1):e53386. Epub 2013 Jan 4. PMID: 23308209; PMCID: PMC3537675. https://doi.org/10.1371/journal.pone.0053386

61. Bhutto IA, Amemiya T. Microvascular architecture of the rat choroid: corrosion cast study. Anat Rec. 2001 Sep 1;264(1):63-71. PMID: 11505372. https://doi.org/10.1002/ar.1102

62. Lutty GA, Hasegawa T, Baba T, Grebe R, Bhutto I, McLeod DS. Development of the human choriocapillaris. Eye (Lond). 2010 Mar;24(3):408-15. Epub 2010 Jan 15. PMID: 20075975; PMCID: PMC4848024. https://doi.org/10.1038/eye.2009.318

63. Fryczkowski AW. Anatomical and functional choroidal lobuli. Int Ophthalmol. 1994;18(3):131-41. PMID: 7852018. https://doi.org/10.1007/BF00915961

64. McLeod DS, Grebe R, Bhutto I, Merges C, Baba T, Lutty GA. Relationship between RPE and choriocapillaris in age-related macular degeneration. Invest Ophthalmol Vis Sci. 2009 Oct;50(10):4982-91. Epub 2009 Apr 8. PMID: 19357355; PMCID: PMC4829357. https://doi.org/10.1167/iovs.09-3639

65. Ninomiya $\mathrm{H}$, Inomata T. Microvasculature of the mouse eye: scanning electron microscopy of vascular corrosion casts. J Exp Anim Sci. 2006 Dec 12;43(3):149-59.

66. Chandrasekera E, An D, McAllister IL, Yu DY, Balaratnasingam C. Three-Dimensional Microscopy Demonstrates Series and Parallel Organization of Human Peripapillary Capillary Plexuses. Invest Ophthalmol Vis Sci. 2018 Sep 4;59(11):4327-4344. PMID: 30193305. https://doi.org/10.1167/iovs.1824105

67. Goldman, D. Simulations of Capillary Network Oxygen Transport During Transient Ischemia in the Presence and Absence of Tissue Myoglobin. In: Wilson DF, Evans SM, Biaglow J, Pastuszko A (editors). Oxygen Transport To Tissue XXIII: Oxygen Measurements in the 21st Century: Basic Techniques and Clinical Relevance. Springer; 2003.pp. 355-359. https://doi.org/10.1007/978-1-4615-0205-0_58

68. Goldman D, Popel AS. A computational study of the effect of capillary network anastomoses and tortuosity on oxygen transport. J Theor Biol. 2000 Sep 21;206(2):181-94. PMID: 10966756. https:// doi.org/10.1006/jtbi.2000.2113

69. Goldman D, Popel AS. A computational study of the effect of vasomotion on oxygen transport from capillary networks. J Theor Biol. 2001 Mar 21;209(2):189-99. PMID: 11401461. https://doi. org/10.1006/jtbi.2000.2254

70. Goldman D, Popel AS. Computational Modeling of Oxygen Transport from Complex Capillary Networks. In: Eke A, Delpy DT (editors). Oxygen Transport to Tissue XXI (eds.) Springer; 1999. pp. 555-563. https://doi.org/10.1007/978-1-4615-4717-4_65

71. Avtar R, Tandon D. Mathematical modelling of intraretinal oxygen partial pressure. Trop J Pharm Res. 2008 Dec 11;7(4):1107-16. 
72. Wangsa-Wirawan ND, Linsenmeier RA. Retinal oxygen: fundamental and clinical aspects. Arch Ophthalmol. 2003 Apr;121(4):547-57. PMID: 12695252. https://doi.org/10.1001/archopht.121.4.547

73. Causin P, Guidoboni G, Malgaroli F, Sacco R, Harris A. Blood flow mechanics and oxygen transport and delivery in the retinal microcirculation: multiscale mathematical modeling and numerical simulation. Biomech Model Mechanobiol. 2016 Jun;15(3):525-42. Epub 2015 Aug 1. PMID: 26232093. https://doi.org/10.1007/s10237-015-0708-7

74. Lamkin-Kennard KA, Buerk DG, Jaron D. Interactions between NO and $\mathrm{O} 2$ in the microcirculation: a mathematical analysis. Microvasc Res. 2004 Jul;68(1):38-50. PMID: 15219419. https://doi. org/10.1016/j.mvr.2004.03.001

75. Yu DY, Cringle SJ, Su EN. Intraretinal oxygen distribution in the monkey retina and the response to systemic hyperoxia. Invest Ophthalmol Vis Sci. 2005 Dec;46(12):4728-33. PMID: 16303972. https:// doi.org/10.1167/iovs.05-0694

76. Yu DY, Cringle SJ. Oxygen distribution in the mouse retina. Invest Ophthalmol Vis Sci. 2006 Mar;47(3):1109-12. PMID: 16505048. https://doi.org/10.1167/iovs.05-1118

77. Yu DY, Cringle SJ. Oxygen distribution in the mouse retina. Invest Ophthalmol Vis Sci. 2006 Mar;47(3):1109-12. PMID: 16505048. https://doi.org/10.1167/iovs.05-1118

78. Przekwas A, Friend T, Teixeira R, Chen ZJ, Wilkerson P. Spatial modeling tools for cell biology. CFD RESEARCH CORP HUNTSVILLE AL; 2006 Oct 1.

79. Roh H-D, Goldstick TK, Linsenmeier RA. Spatial variation of the local tissue oxygen diffusion coefficient measured in situ in the cat retina and cornea. In: Oxygen Transport to Tissue XII. Springer: 1990. pp. 127-136.

80. Goldstick TK, Ciuryla VT, Zuckerman L. Diffusion of oxygen in plasma and blood. Adv Exp Med Biol. 1976;75:183-190.

81. Malinski T, Taha Z, Grunfeld S, Patton S, Kapturczak M, Tomboulian P. Diffusion of nitric oxide in the aorta wall monitored in situ by porphyrinic microsensors. Biochem Biophys Res Commun. 1993 Jun 30;193(3):1076-82. 1993.1735. PMID: 8323533. https://doi.org/10.1006/bbrc

82. Linsenmeier RA, Braun RD. Oxygen distribution and consumption in the cat retina during normoxia and hypoxemia. J Gen Physiol. 1992 Feb;99(2):177-97. PMID: 1613482; PMCID: PMC2216610. https:// doi.org/10.1085/jgp.99.2.177

83. Billett HH. Hemoglobin and Hematocrit. In: Walker HK, Hall WD, Hurst JW (editors). Clinical Methods: The History, Physical, and Laboratory Examinations. Butterworths; 1990.

84. Hedrich $\mathrm{H}$. The laboratory mouse. Academic Press; 2004.

85. Black DM, Gilardi KV, Hamilton LP, Williams E, Williams DF, Kelly PA, Gardner I. Hematologic and biochemistry reference values for the endangered riparian brush rabbit (Sylvilagus bachmani riparius). J Wildl Dis. 2009 Apr;45(2):491-6. PMID: 19395758. https://doi.org/10.7589/0090-3558-45.2.491

86. Quaknine-Orlando B, Samama CM, Riou B, Bonnin P, Guillosson JJ, Beaumont JL, Coriat P. Role of the hematocrit in a rabbit model of arterial thrombosis and bleeding. Anesthesiology. 1999 May;90(5):1454-61. PMID: 10319795. https://doi.org/10.1097/00000542-199905000-00031

87. Moore JA, Ethier CR. Oxygen mass transfer calculations in large arteries. J Biomech Eng. 1997 Nov;119(4):469-75. PMID: 9407287. https://doi.org/10.1115/1.2798295 
88. Shimizu S, Enoki Y, Kohzuki H, Ohga Y, Sakata S. Determination of Hüfner's factor and inactive hemoglobins in human, canine, and murine blood. Jpn J Physiol. 1986;36(5):1047-51. PMID: 3560533. https://doi.org/10.2170/jjphysiol.36.1047

89. Palkovits S, Told R, Schmidl D, Boltz A, Napora KJ, Lasta M, Kaya S, Werkmeister RM, Popa-Cherecheanu A, Garhöfer G, Schmetterer L. Regulation of retinal oxygen metabolism in humans during graded hypoxia. Am J Physiol Heart Circ Physiol. 2014 Nov 15;307(10):H1412-8. Epub 2014 Sep 12. PMID: 25217648. https://doi.org/10.1152/ajpheart.00479.2014

90. Blair NP, Wanek J, Felder AE, Brewer KC, Joslin CE, Shahidi M. Inner Retinal Oxygen Delivery, Metabolism, and Extraction Fraction in Ins2Akita Diabetic Mice. Invest Ophthalmol Vis Sci. 2016 Nov 1;57(14):5903-5909. PMID: 27802520; PMCID: PMC5096417. https://doi.org/10.1167/iovs.16-20082

91. Linsenmeier RA, Zhang HF. Retinal oxygen: from animals to humans. Prog Retin Eye Res. 2017 May;58:115-151. Epub 2017 Jan 18. PMID: 28109737; PMCID: PMC5441959. https://doi.org/10.1016/j. preteyeres.2017.01.003

92. Sobecki R. [Studies on oxygen content in aqueous humor of the anterior chamber of the rabbit's eye--I. Oxygen content in aqueous humor of anterior chamber and arterial blood under physiologic conditions]. Klin Oczna 1993;95161-162.

93. Carlsen $\mathrm{E}$, Comroe $\mathrm{JH}$. The rate of uptake of carbon monoxide and of nitric oxide by normal human erythrocytes and experimentally produced spherocytes. J Gen Physiol. 1958;42:83-107.

94. Vaughn MW, Kuo L, Liao JC. Estimation of nitric oxide production and reaction rates in tissue by use of a mathematical model. Am J Physiol. 1998 Jun;274(6):H2163-76. PMID: 9841542. https://doi. org/10.1152/ajpheart.1998.274.6.H2163

95. Vaughn MW, Kuo L, Liao JC. Effective diffusion distance of nitric oxide in the microcirculation. Am J Physiol. 1998 May;274(5):H1705-14. PMID: 9612383. https://doi.org/10.1152/ ajpheart.1998.274.5.H1705

96. Thomas DD, Liu X, Kantrow SP, Lancaster JR Jr. The biological lifetime of nitric oxide: implications for the perivascular dynamics of NO and O2. Proc Natl Acad Sci U S A. 2001 Jan 2;98(1):355-60. PMID: 11134509; PMCID: PMC14594. https://doi.org/10.1073/pnas.011379598

97. Gray LH, Steadman JM. Determination of the oxyhaemoglobin dissociation curves for mouse and rat blood. J Physiol. 1964;175:161-171.

98. Jelkmann W, Bauer C. Oxygen affinity and phosphate compounds of red blood cells during intrauterine development of rabbits. Pflügers Archiv. 1977;372:149-156.

99. Dalbey K, et al. Dakota A Multilevel Parallel Object-Oriented Framework for Design Optimization Parameter Estimation Uncertainty Quantification and Sensitivity Analysis: Version 6.12 Theory Manual. Available from: https://www.osti.gov/biblio/1630693 (2020). https://doi.org/10.2172/1630693

100. Linsenmeier RA. Effects of light and darkness on oxygen distribution and consumption in the cat retina. J Gen Physiol. 1986 Oct;88(4):521-42. PMID: 3783124; PMCID: PMC2228847. https://doi. org/10.1085/jgp.88.4.521

101. Kaufman PL, Levin LA, Adler FH, Alm A. Adler's Physiology of the Eye. Elsevier Health Sciences; 2011.

102. Harris A, Kagemann L, Cioffi GA. Assessment of human ocular hemodynamics. Surv Ophthalmol. 1998 May-Jun;42(6):509-33. PMID: 9635901. https://doi.org/10.1016/s0039-6257(98)00011-3 
103. Hall CN, Garthwaite J. What is the real physiological NO concentration in vivo? Nitric Oxide. 2009 Sep;21(2):92-103. Epub 2009 Jul 12. PMID: 19602444; PMCID: PMC2779337. https://doi.org/10.1016/j. niox.2009.07.002

104. Roberts PA, Gaffney EA, Luthert PJ, Foss AJE, Byrne HM. Mathematical and computational models of the retina in health, development and disease. Prog Retin Eye Res. 2016 Jul;53:48-69. Epub 2016 Apr 7. PMID: 27063291. https://doi.org/10.1016/j.preteyeres.2016.04.001

105. Scott A, Fruttiger M. Oxygen-induced retinopathy: a model for vascular pathology in the retina. Eye (Lond). 2010 Mar;24(3):416-21. Epub 2009 Dec 11. PMID: 20010791. https://doi.org/10.1038/ eye.2009.306

106. Fu Y, Dong Y, Gao Q. Age-related cataract and macular degeneration: Oxygen receptor dysfunction diseases. Med Hypotheses. 2015 Sep;85(3):272-5. Epub 2015 Jun 1. PMID: 26049822. https://doi. org/10.1016/j.mehy.2015.05.020

107. Thomas DD. Breathing new life into nitric oxide signaling: A brief overview of the interplay between oxygen and nitric oxide. Redox Biol. 2015 Aug;5:225-233. Epub 2015 May 22. PMID: 26056766; PMCID: PMC4473092. https://doi.org/10.1016/j.redox.2015.05.002

108. German C, Pilvankar M, Przekwas A. Computational framework for predictive PBPK-PD-Tox simulations of opioids and antidotes. J Pharmacokinet Pharmacodyn. 2019 Dec;46(6):513-529. Epub 2019 Aug 8. PMID: 31396799. https://doi.org/10.1007/s10928-019-09648-1 


\section{Appendix 1}

\section{Oxygen transport in blood}

Oxygen in the blood is carried in plasma and in the red blood cells (RBCs) in three forms:

- dissolved free oxygen in plasma, $\mathrm{O}_{2, \mathrm{p}}$,

- dissolved in the intracellular fluid in RBSs, $\mathrm{O}_{2, \mathrm{R}}$, and

- reversibly bound to hemoglobin $(\mathrm{Hb})$ inside of $\mathrm{RBCs}, \mathrm{O}_{2, \mathrm{Hb}}$.

The dissolved $\mathrm{O}_{2}$ concentration $\mathrm{C}_{\mathrm{O} 2}\left[\mathrm{~mL} \mathrm{O}_{2} / \mathrm{cm}^{3}\right]$ is related to its partial pressure, $\mathrm{P}_{\mathrm{O} 2}$ [mmHg] via Henry's law:

$$
\mathrm{C}_{02}=\mathrm{aP}_{\mathrm{O} 2}
$$

where $\alpha$ is the oxygen solubility coefficient $\left[\mathrm{mL} \mathrm{O}_{2} / \mathrm{mmHg} / \mathrm{cm}^{3}\right]$.

The reaction between $\mathrm{O}_{2}$ and $\mathrm{Hb}$ in RBCs is described by the Adair equation, ${ }^{1}$ or in simplified form by the Hill equation, ${ }^{2}$ describing the $\mathrm{O}_{2}-\mathrm{Hb}$ equilibrium curve in terms of percent oxygen saturation of hemoglobin, $S$, versus oxygen tension, $P$ :

$$
S(P)=\frac{P^{n}}{P_{50}^{n}+P^{n}}
$$

where $P_{50}$ is the oxygen partial pressure at $\mathrm{Hb}$ half-saturation and the exponent $n$ is referred to as the Hill exponent. This is a "one-step" reaction approximation for oxygen binding to the four heme groups of the $\mathrm{Hb}$ molecule and is a good approximation of the Adair equation for the physiological range $20 \%$ to $97 \%$ saturation. ${ }^{2}$

The conservation equation for blood oxygen in terms of partial pressure can be derived from the model presented by Goldman and Popel, ${ }^{3,4}$ where the total concentration of free and $\mathrm{Hb}$ bound $\mathrm{O}_{2}$ in blood (in terms of partial pressure) is given by:

$$
P_{b}=a_{P l} P_{P l}(1-H)+a_{R} P_{R} H+C_{H b} S \cdot H
$$

where $P_{b}$ is the total partial pressure of $\mathrm{O}_{2}$ in blood, $\alpha_{P l}$ and $\alpha_{R}$ are the oxygen solubilities $\left(\mathrm{mL} \mathrm{O}_{2} / \mathrm{mmHg} / \mathrm{m}^{3}\right)$ in plasma and in intracellular fluid of RBCs, $P_{P l}$ and $P_{R}$ are the partial pressures of dissolved oxygen in plasma and RBC fluids, $H$ is the hematocrit and $C_{H b}$ is the oxygen binding capacity of $\mathrm{Hb}$. 
Oxygen transport can be determined by taking partial derivatives of Equation 3 with respect to time, $t$, and a spatial direction, $x$. Here, these equations are presented separately for plasma and RBCs, respectively:

$$
\begin{aligned}
& (1-H) \frac{\partial \alpha_{P I} P_{P l}}{\partial t}+u_{b}(1-H) \frac{\partial \alpha_{P l} P_{P l}}{\partial x}=R_{R-P L}-j_{P L-T} \\
& H \frac{\partial\left(\alpha_{R} P_{R}+C_{H b} S\right)}{\partial t}+u_{b} \cdot H \frac{\partial\left(\alpha_{R} P_{R}+C_{H b} S\right)}{\partial x}=-R_{R-P L}
\end{aligned}
$$

where $u_{b}$ is the blood velocity $(\mathrm{m} / \mathrm{s}), R_{R-P L}$ is the plasma-RBC oxygen exchange rate and $j_{P L-T}$ is a flux term representing oxygen exchange between plasma and tissue.

Assuming that the partial pressure of oxygen in plasma and RBC intracellular fluid are in equilibrium $\left(P_{P l}=P_{R}=P_{b}\right)$, we can combine Equations 4 and 5 to obtain a single oxygen transport equation for blood:

$$
\left(a_{b} \frac{\partial P_{b}}{\partial t}+H \cdot C_{H b} \frac{\partial S}{\partial t}\right)+u_{b} \cdot\left(a_{b} \frac{\partial P_{b}}{\partial x}+H \cdot C_{H b} \frac{\partial S}{\partial t}\right)=-J_{B T}
$$

where $J_{B T}$ is the blood-tissue oxygen flux (equivalent to $j_{P L-T}$ ) and blood solubility, $a_{\mathrm{b}}$ , is calculated by:

$$
a_{b}=a_{P l}(1-H)+a_{R} H
$$

Equation 6 has two dependent variables, $P_{b}$ and $S$. To obtain a homogenous equation for $P_{b}$ we expand the temporal derivative of $S$ as a function of $P_{b}$ :

$$
\left(a_{b}+H \cdot c_{H b} \frac{\partial S}{\partial t}\right) \frac{\partial P_{b}}{\partial t}+u_{b}\left(a_{b}+H \cdot c_{H b} \frac{d S}{d t}\right) \frac{\partial P_{b}}{\partial x}=-J_{B T}
$$

For further simplification of the differential equation let's define parameter $B$ :

$$
B=\left(a_{b}+H \cdot c_{H B} \frac{d S}{d P}\right)
$$

The nonlinear term, $d S / d P$, can be calculated analytically by differentiation of Equation 2:

$$
\frac{d S}{d P}=\frac{n \cdot P_{b}^{(n-1)} \cdot P_{b 50}{ }^{n}}{\left(P_{b 50}{ }^{n}+P_{b}{ }^{n}\right)^{2}}
$$

Substituting Equation 10 into Equation 9 we have:

$$
B=\left(a_{b}+H \cdot C_{H B}\left(\frac{n \cdot P^{(n-1)} \cdot P_{50}^{n}}{\left(P_{50}^{n}+P^{n}\right)}\right)\right)
$$

With the above we can rewrite Equation 8 in the final homogenous partial differen- 
tial transport equation for $P_{b}$ as:

$$
B\left(\frac{\partial P_{b}}{\partial t}+u_{b} \frac{\partial P_{b}}{\partial x}\right)=-J_{B T}
$$

To express the above equation in a compartmental form we can integrate it over the compartmental control volume, $V=A \Delta x$ :

$$
\int_{V}^{0} B\left(\frac{\partial P_{b}}{\partial t}+u_{b} \frac{\partial P_{b}}{\partial x}\right) d V=\int_{V}^{0} j_{B T} d V
$$

After integration we get:

$$
V \frac{d P_{b}}{d t}+A \cdot \Delta x \cdot u_{b} \frac{\Delta P_{b}}{\Delta x}=\frac{-J_{B T}}{B}
$$

and using the definition of the blood flow rate, $Q_{b}=A u_{b}$ :

$$
V \frac{d P_{b}}{d t}+Q_{b} \Delta P_{b}=\frac{-J_{B T}}{B}
$$

The final version of the oxygen transport equation expressed in the form of an ordinary different equation is:

$$
\left.\frac{d P_{b}}{d t}=\frac{1}{V_{b}}\left[-Q\left(P_{b}-P_{0}\right)-\frac{J_{B T}}{(B}\right)\right]
$$

where $P_{0}$ is the oxygen partial pressure entering the vascular compartment, assumed equivalent to systemic oxygen partial pressure.

\section{Supplementary references}

1. Winslow RM, Swenberg ML, Berger RL, Shrager RI, Luzzana M, Samaja M, Rossi-Bernardi L. Oxygen equilibrium curve of normal human blood and its evaluation by Adair's equation. J Biol Chem. 1977;252(7):2331-7. PMID: 849931.

2. O'Riordan JF, Goldstick TK, Ditzel J, Ernest JT. Characterization of Oxygen-Hemoglobin Equilibrium Curves Using Nonlinear Regression of the Hill Equation: Parameter Values for Normal Human Adults. In: Bicher HI, Bruley DF (eds). Oxygen Transport to Tissue-IV. Advances in Experimental Medicine and Biology, vol 159. Springer: Boston, MA; 1983. https://doi.org/10.1007/978-1-4684-7790-0_37

3. Goldman D, Popel AS. A computational study of the effect of capillary network anastomoses and tortuosity on oxygen transport. J Theor Biol. 2000;206(2):181-94. https://doi.org/10.1006/jtbi.2000.2113

4. Goldman D, Popel AS. A computational study of the effect of vasomotion on oxygen transport from capillary networks. J Theor Biol. 2001;209(2):189-99. https://doi.org/10.1006/jtbi.2000.2254. PMID: 11401461 


\section{Appendix 2}

Final model equations for oxygen transport $\left(\mathrm{O}_{2}\right.$ only) and metabolism by species

\section{Human model}

Blood transport

Superficial vascular plexus (SVP)

$$
\left.\frac{\underline{d P_{S V P}}}{\underline{d t}}=\frac{1}{V_{S V P}} \frac{J_{B T, S V P}}{\left[\left(a_{b}+H \cdot C_{H b}\left(\frac{n \cdot P_{S P P}^{n-1} \cdot P_{50}{ }^{n}}{\left(P_{50}{ }^{n}+P_{S V P}\right)^{2}}\right)\right)\right.}-Q_{S V P}\left(P_{S V P}-P_{0}\right)\right]
$$

$\underline{\text { Intermediate capillary plexus (ICP) }}$

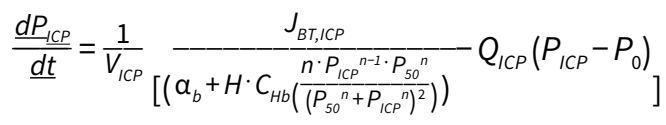

Deep capillary plexus (DCP)

$$
\left.\frac{d P_{D C P}}{\underline{d t}}=\frac{1}{V_{D C P}} \frac{J_{B T, D C P}}{\left[\left(\alpha_{b}+H \cdot C_{H b}\left(\frac{n \cdot P_{D C P}{ }^{n-1} \cdot P_{50}{ }^{n}}{\left(P_{50}+P_{D C P}\right)^{2}}\right)\right)\right.}-Q_{D C P}\left(P_{D C P}-P_{0}\right)\right]
$$

Choriocapillaris (CIA)

$$
\frac{d P_{C I A}}{\underline{d t}}=\frac{1}{V_{C I A}} \frac{J_{B T, C I A}}{\left[\left(a_{b}+H \cdot C_{H b}\left(\frac{n \cdot P_{C \mid A}^{n-1} \cdot P_{50}{ }^{n}}{\left(P_{50}+P_{C I A}\right)^{2}}\right)\right)\right.}-Q_{C I A}\left(P_{C I A}-P_{0}\right)_{]}
$$


Blood-tissue fluxes:

$$
\begin{aligned}
& J_{B T, S V P}=K_{b t, S V P} \cdot A_{b t, S V P}\left(a_{t} P_{G C L}-a_{b} P_{S V P}\right) \\
& J_{B T, I C P}=K_{b t, I C P} \cdot A_{b t, I C P}\left(a_{t} P_{I P L}-a_{b} P_{I C P}\right) \\
& J_{B T, D C P}=K_{b t, D C P} \cdot A_{b t, D C P}\left(a_{t} P_{O P L}-a_{b} P_{D C P}\right) \\
& J_{B T, C I A}=K_{b t, C I A} \cdot A_{b t, C I A}\left(a_{t} P_{C}-a_{b} P_{C I A}\right)
\end{aligned}
$$

\section{Tissue transport:}

Vitreous (VIT)

$$
\frac{d P_{V I T}}{d t}=0
$$

Nerve fiber layer (NFL)

$$
a_{t} \cdot \frac{d P_{N F L}}{d t}=\frac{1}{V_{N F L}}\left(J_{N F L_{-} G C L}-J_{V I T_{-} N F L}-R_{N F L} \cdot V_{N F L}\right)
$$

Ganglion cell layer (GCL)

$$
a_{t} \cdot \frac{d P_{G C L}}{d t}=\frac{1}{V_{G C L}}\left(J_{G C L \_I P L}-J_{N F L_{G C L}}-R_{G C L} \cdot V_{G C L}-\frac{J_{B T, S V P}}{a_{t}}\right)
$$

$\underline{\text { Inner Plexiform Layer (IPL) }}$

$$
\alpha_{t} \cdot \frac{d P_{I P L}}{d t}=\frac{1}{V_{I P L}}\left(J_{I P L \_I N L}-J_{G C L}-R_{I P L} \cdot V_{I P L}-\frac{J_{B T, I C P}}{\alpha_{t}}\right)
$$

$\underline{\text { Inner nuclear layer (INL) }}$

$$
a_{t} \cdot \frac{d P_{I N L}}{d t}=\frac{1}{V_{I N L}}\left(J_{I N L \_O P L}-J_{I P L \_I N L}-R_{I N L} \cdot V_{I N L}\right)
$$

Outer plexiform layer (OPL)

$$
a_{t} \cdot \frac{d P_{O P L}}{d t}=\frac{1}{V_{O P L}}\left(J_{O P L_{-} O N L}-J_{I N L_{O P L}}-R_{O P L} \cdot V_{O P I}-\frac{J_{B T, D C P}}{a_{t}}\right)
$$


42

C. German, A. Boyer, A. Przekwas et al.

Outer nuclear layer (ONL)

$$
a_{t} \cdot \frac{d P_{O N L}}{d t}=\frac{1}{V_{O N L}}\left(J_{O N L \_P L}-J_{O P L \_O N L}-R_{O N L} \cdot V_{O N L}\right)
$$

Photoreceptor layer (PL)

$$
\alpha_{t} \cdot \frac{d P_{P L}}{d t}=\frac{1}{V_{P L}}\left(J_{P L_{R} R P E}-J_{O N L_{P} P L}-R_{P L} \cdot V_{P L}\right)
$$

Retinal pigmented epithelium (RPE)

$$
a_{t} \cdot \frac{d P_{R P E}}{d t}=\frac{1}{V_{R P E}}\left(J_{C_{-} R P E}-J_{P L_{-} R P E}-R_{R P E} \cdot V_{R P E}\right)
$$

Choroid (C)

$$
a_{t} \cdot \frac{d P_{C}}{d t}=\frac{1}{V_{c}}\left(J_{S_{-} C}-J_{C_{R P E}}-R_{C} \cdot V_{C}-\frac{J_{B T, C I A}}{\alpha_{t}}\right)
$$

Sclera (S)

$$
a_{t} \cdot \frac{d P_{S}}{d t}=\frac{1}{V_{c}}\left(J_{E_{-} S}-J_{S_{-} C} \cdot R_{S} \cdot V_{S}\right)
$$

Tissue-tissue fluxes:

$$
\begin{aligned}
& J_{\text {VIT_NFL }}=K_{\text {tt,VIT_NFL }} \cdot A_{\text {retina }}\left(P_{\text {NFL }}-P_{\text {VITa }}\right) \\
& J_{N F L_{-} G C L}=K_{\text {tt,NFL_GCL }} \cdot A_{\text {retina }}\left(P_{G C L}-P_{\text {NFL }}\right) \\
& J_{G C L \_I P L}=K_{t t, I P L G C L} \cdot A_{\text {retina }}\left(P_{I P L}-P_{G C L}\right) \\
& J_{I P L \_I N L}=K_{t t, I P L \_I N L} \cdot A_{\text {retina }}\left(P_{I N L}-P_{I P L}\right) \\
& J_{\text {OPL_ONL }}=K_{\text {tt,OPL_ONL }} \cdot A_{\text {retina }}\left(P_{\text {eNL }}-P_{\text {OP }}\right) \\
& J_{\text {ONL_Pl }}=K_{t t, O N L_{P} P l} \cdot A_{\text {retina }}\left(P_{P L}-P_{\text {eNL }}\right) \\
& J_{R P E_{-} C}=K_{t t, R P E_{-} C} \cdot A_{\text {retina }}\left(P_{C}-P_{R P E}\right) \\
& J_{C_{-} S}=K_{t t, C_{-} S} \cdot A_{\text {retina }}\left(P_{S}-P_{c}\right) \\
& J_{E_{-} S}=K_{t t, E_{-} S} \cdot A_{\text {retina }}\left(0-P_{S}\right)
\end{aligned}
$$

